The Education Committee reported that more than 12,000 children with discharging ears are in attendance at school. Some 7,000 children have easily appreciable deafness, and in addition, 800 children attend deaf schools or " hard of hearing" classes. About 800 children of school age die in London annually from diseases closely associated with ear disease.

THE twenty-seventh French Congress of Surgery will be held in Paris in October (7th to 10th). The following are the questions officially proposed for discussion: Extraction of intrathoracic projectiles; treatment of remote results of nerve lesions caused by war projectiles; removal of splinters and repair of losses of bone substance. There will be no introductory reports on these subjects. The general secretary of the Congress is Dr J. L. Faure, 10, rue de Seine, Paris, from whom any further information can be obtained.

'THE Ministry of Munitions has made an order prohibiting the sale, except under licence, of radio-active substances, luminous bodies and ores. The order applies to all. radioactive substances (including actinium, radium, uranium, thorium and their disintegration products and compounds), luminous bodies in the preparation of which any radioactive substance is used, and ores from which any radioactive substance is obtainable, except uranium nitrate and except radio-active substances at the date of the order forming an integral part of any instrument, including instruments of precision or for timekeeping.

A NEW edition of The Nomenclature of Diseases bas been issued (H.M. Stationery Offlce; 2s. net). All the editions have been prepared by joint committees appointed by the Royal College of Physicians of London. The first was completed in 1869, the second was published in 1884, the third in 1896, and the fourth in 1906. 'The secretary and editor of the committee of the new edition was Dr. 1,eonard Guthrie. It had numerous subcommittees dealing with diseases of various systems. Among the changes introduced in the new edition is the substitution of the term "diseases caused by infection " for "infective diseases," and three new groups have been formed for diseases of the blood, and of the ductless or endocrine glands, and for disorders of nutrition or metabolism. The lists of tumours, parasites, and malformations have been rewritten and numerous additions made. A difficulty has been encountered in the nomenclature of diseases of the nervous system, which include a large and heterogeneous group at present only to be classified as " names of symptoms, groups of symptoms, diseases named with reference to their symptoms, and diseases of which the pathogenesis is not accurately known.'

A REVISED version of the regulations under which grants are payable by the Board of Education to day nurseries in England and Wales has been issued (Cd. 9129. Price, 1d.). The revision provides for the payment of a grant at a rate not exceeding 50 per cent. of the net expenditure after deducting any payments made for the care of children, and other similar receipts. The increased grants payable during the current financial year will be based on the expenditure incurred during the twelve months ending on March 31st, 1918. In fixing the rate of grant the Board will have particular regard to the provision for the medical inspection and supervision of the infants and young children, the number and qualifications of the staff, the provisions for promoting physical welfare and the prevention of infectious diseases, the suitability of the premises and equipment, and the methods adopted for confining the benefits to infants and young children who, by reason of the necessary absence of the mother at work or other similar cause, cannot be adequately cared for at home.

THE Royal Society has arranged a conference of representatives of the allied nations to meet on October 9th in loondon to discuss the future conduct of scientific work hitherto carried on by international organizatious. It is expected that representatives from the academies of Paris, Rome, 'Tokyo, and Washington, and nominees of the Governments of Belgium, Portugal, and Serbia, will attend. The conference will chiefly be concerned with those departments of science in which international cooperation is most essential, such as mensuration and electric standards, geodesy and seismology, and the photorraphic chart of the heavens. Amons other matters which will have attention are international meetings of mathematicians, geologists, and botanists, and the work of the International Association of Academies, which aims at co-ordinating the activities of international under takings and organizing work for which special bodies do not exist or are not required. : The main object of the conferenoe will be to agree on a common policy with regard to matters which depend on Government support.

\section{马etters, flates, and Antures.}

IN order to avoid delay, it is particularly requested that ALL letters on the editorial business of the JOURNAL be addressed to the Editor at the Office of the JOURNAL. The postal address of the BRIrish MEDICAL Association and 1.

1. EDITOR of the BRITIsh MEDICAL Journal, Aitiology, 2. FINANCIAL SECRETARY AND BUSINESS MANAGER (Advertisements, etc.), Articulate, Westrand,London; telephone, 2630, Gerrard.

3. MEDICAL SECRETARY, Medisecra, Westrand, London elephone, 2634, Gerrard. The address of the Irish Oftice of th British Medical Association is 16, South Frederick Street, Dublin. The address of the Central Medical War Committe for England and Wales is 429, Strand, London, W.C.2; that of the Reference Colleges in London is the Examination Hall, 8, Queen square, Bloomsbury, W.C.l; and that of the Scottish Medical Service Emergency Committeo is Royal College of
Physicians, Edinburgh.

QUERIES AND ANGWERS.

AUTO-WHEELS.

Dr. T. Reuell AtKinson (Chadwell Heath) writes, in reply to "Aloin," to call attention to a note by himself in which he spoke well of the ato.wheel (BRITISH MEDICAL JourNAI December 9th, 1916, p. 828). Wet weather, he adds, makes no difference provided one does not weather, he adds, makes no difference provided one does not clean one's own machine; it picks up dirt. Against a strong wind a little foot pedalling gradients easily enough, but help with the feet is needed on very steep hills.

DeCline of THE Birth-RATE.

Custos wishes to know whether, apart from the subject of eugenics, there exists a society which interests itself in mean for arresting the decline in the birth-rate, especially in the midule and upper classes, which could give him information capable of being worked into a lecture or pamphlet for the young officer class.

** Our correspondent might write to the Secretary, National Council of Public Morals, 20, Bedford Square, W.C.1. This body has, we believe, collected much information of the kind desired. "Custos" must, however, use his own judgement as to the scientific value of the literature in yuestion.

\section{LETTERS NOTES, ETC.}

LONDON's MEDICAL SHERIFF.

Dr. Clippingdale (London, W.) writes: The election of Dr. W. K. Smith, professor of toxicology in King's College, to the shrievalty of London exemplifies the rarity with which medical men have been elected to the highest with which within the City of London. Such elections in former posts were always made by the twelve upper livery companies, were always made by the twelve upper livery companies, which did not include the two semi-medical bodies-namely, Thomas Crosby was the first and at present remains the only medical man to hold the office of Lord Mayor. Sheriff Smith in the honour he has accepted seems to have had only two medical predecessors-Thomas Horesbede (surgeon to King Henry V), who was sheriff in 1436, and Sir John Ayliffe (surgeon to King Henry VIII), who was sheriff in 1548.

$$
\text { The Bell Fund. }
$$

DR. S. A. KINNIER WILSON asks us to acknowledge the following donations to the Dr. J. H. Bell Fund: Sir Hugh Rigby $£ 10$ 10s., Lieut. Colonel E. Farquhar Buzzard £5 5s., Dr. David Dinwoodie $£ 1$ ls., Captain Ralph R. Watts, R.A.M.C., £1 1s. Subscriptions should be sent to Dr. Wilson at 14, Harley street, London, W. 1.

Septicaemia Due to Mixed Infection. A Correction.

THE bacillus found in the blood of the case recorded by Dr. B. Henry Shaw (British Medical Journal, August 10th, p. 133), of a man suffering from septicaemia, was the Bacillus septus, or $B$. coryzae segmentosus, not, as printed, the B. septicus.

GCALE OF CHARGES FOR ADYERTIBEMENTS IN THE BRITISH MEDICAL JOURNAL.

Seven lines and under

Each additional lin

Whole page

An averä

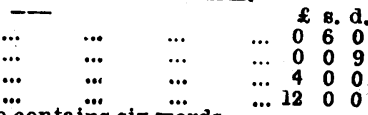

All remittances by Post Office Orders must be made payable to No - responsibility will be accepted for any such remittance London. safeguarded.

Advertisements should be delivered, addressed to the Manager, 429, Strand, London, not later than the first post on Wednesday morning preceding publication, and, if not paid for at the time, should bo

Nome - It is against the rules of the Post Office to receive posto
Nome 